\title{
Dynamical Downscaling for Southeast Alaska: Historical Climate and Future Projections
}

\author{
RICK LADER \\ Alaska Climate Adaptation Science Center, International Arctic Research Center, University of Alaska Fairbanks, \\ Fairbanks, Alaska \\ ALLISON BIDLACK \\ Alaska Climate Adaptation Science Center, International Arctic Research Center, University of Alaska Fairbanks, \\ Fairbanks, and Alaska Coastal Rainforest Center, University of Alaska Southeast, Juneau, Alaska \\ JOHN E. WALSH \\ International Arctic Research Center, University of Alaska Fairbanks, Fairbanks, Alaska \\ UMA S. BHATT \\ Alaska Climate Adaptation Science Center, International Arctic Research Center, University of \\ Alaska Fairbanks, Fairbanks, Alaska \\ Peter A. Bieniek \\ International Arctic Research Center, University of Alaska Fairbanks, Fairbanks, Alaska
}

(Manuscript received 24 March 2020, in final form 24 July 2020)

\begin{abstract}
Warming temperatures across southeast Alaska are affecting the region's energy and transportation sectors, marine ecosystems, and forest health. More frequent above-freezing temperatures lead a transition from snow- to raindominant precipitation regimes, accelerating glacial mass balance loss and a leading to a greater risk for warm-season drought. Southeast Alaska has steep topographical gradients, which necessitate the use of downscaled climate information to study historical and projected periods. This study used regional dynamical downscaling at 4-km spatial resolution with the Weather Research and Forecasting Model to assess historical (1981-2010) and projected (2031-60) climate states for southeast Alaska. These simulations were driven by one reanalysis (i.e., the Climate Forecast System Reanalysis) and two climate models (i.e., the Geophysical Fluid Dynamics Laboratory Climate Model, version 3, and the NCAR Community Climate System Model, version 4), which each included a historical simulation and a projected simulation. The future simulations used the representative concentration pathway 8.5 emissions scenario. Bias-corrected projections (203160 minus 1981-2010) indicated seasonal warming of $1^{\circ}-3^{\circ} \mathrm{C}$, increased precipitation during autumn $(4 \%-12 \%)$ and winter (7\%-12\%), and decreased snowfall in all seasons (up to $60 \%$ in autumn). The average number of days annually with a minimum temperature below freezing dropped by more than 30 . The average annual maximum consecutive 3-day precipitation amounts increased by $11 \%-16 \%$, but analogous extreme snowfall amounts dropped by $5 \%-11 \%$. The most substantial snow losses occurred at low-elevation and coastal locations; at many high elevations (e.g., above $1000 \mathrm{~m}$ ), extreme snowfall amounts increased.
\end{abstract}

KEYWORDS: Extreme events; Regional models

\section{Introduction}

Southeast Alaska is a climatologically diverse region that is experiencing unprecedented changes due to recent warming. It is located in a transition zone between the Arctic and the extratropics, dominated primarily by temperate coastal rain forest and expansive alpine glaciers. A 64-yr analysis from 1949 to 2012 found that temperatures in this region had risen $1.0^{\circ}-$ $1.4^{\circ} \mathrm{C}$ with significant increases ( $p \leq 0.05$; two-tailed $t$ test) in winter and spring (Bieniek et al. 2014). Warming has continued across Alaska since 2012, with the top three warmest years occurring statewide in 2019, 2016, and 2018 (Gleason et al. 2019; NOAA National Centers for Environmental Information 2020).

Corresponding author: Rick Lader, rtladerjr@alaska.edu
The 2019 record also marked the first time that the average statewide temperature has been above freezing (NOAA National Centers for Environmental Information 2020). Glaciers in the region are experiencing record high snow lines and an increasing rate of mass balance loss (Pelto and World Glacier Monitoring Service 2019).

The Gulf of Alaska regulates the climate of southeast Alaska, and it has also experienced multiple record high temperatures within the past five years. Several studies have shown that anthropogenic warming increased the likelihood of the 2016 records of sea surface temperature and ocean heat content (Oliver et al. 2018; Walsh et al. 2018a). This marine heat wave has further been linked to destructive impacts that propagated through the marine food webs of south coastal Alaska, including harmful algal blooms, lower nutrient density, 
increased disease, and fish and bird die-offs (Walsh et al. 2018a). Globally 2016 was also the warmest year of record, and although it came at the end of an El Niño, which typically leads to warmer temperatures, the magnitude of the positive global anomaly was found to be only possible when including anthropogenic forcing (Knutson et al. 2018).

Southeast Alaska is prone to extreme multiday precipitation events, resulting from moisture plumes known as atmospheric rivers (ARs), which transport tremendous amounts of moisture northward from the subtropics and central Pacific (Zhu and Newell 1994). The combination of favorable dynamical forcing and orographic effects upon interaction with the land can result in localized AR event amounts greater than $10 \%$ of mean annual precipitation in Alaska (Papineau and Holloway 2011). Case studies of these Alaska events show they typically occur from autumn through early winter, can produce precipitation amounts exceeding $50 \mathrm{~cm}$, and can cause flooding, landslides, and debris flows, which further lead to deleterious human impacts (Jacobs et al. 2016). ARs in the western United States are associated with $31 \%-65 \%$ of avalanche fatalities in coastal climate zones (Hatchett et al. 2017) and single AR events can produce $10 \%-25 \%$ of total snowpack snow water equivalent (Serreze et al. 2001). Continued warming is expected to increase the total number of ARs that impact the west coast of North America (Tan et al. 2020). Trends of annual precipitation across southeast Alaska from 1969 to 2018 show increases ranging from $4.7 \%$ to $15.1 \%$ (Thoman and Walsh 2019).

Given this region's orography and typical abundance of precipitation, a network of hydropower facilities has been established and is used to generate electricity for many communities. However, there are several precipitation-related issues that can jeopardize the reliability of this energy source. Avalanches can disrupt transmission lines, low snowfall amounts reduce the storage buffer that can be used for keeping reservoir levels sufficiently high during spring and summer, and drought can all put the region at risk (Cherry et al. 2010). In 2019, parts of southeast Alaska experienced their first extreme drought conditions of record as categorized by the U.S. Drought Monitor; these not only limited hydropower activity but also led to the imposition of water restrictions, pest problems, and altered the timing of salmon runs (Bathke et al. 2019). As temperatures continue to warm and glaciers melt, the timing of precipitation will become more important with the loss of this additional water storage buffer (Berman and Schmidt 2019).

Further warming will alter the hydrological cycle by forcing an earlier peak runoff, and limited storage capacity will lead to the loss of excess runoff. This could necessitate a trade-off decision being made to either release water to support salmon runs or to generate electricity from hydropower to meet peak demand (Barnett et al. 2005). Warming is also expected to be elevation dependent such that higher locations will experience greater warming than lower regions, which portends changing rain/snow characteristics (Pepin et al. 2015). Significant reductions in the winter (November-March) snowfall/precipitation ratios have already been observed in the contiguous United States (Feng and Hu 2007), as have less frequent high-extreme snowfall years (Kunkel et al. 2009), with some regional variation. With both of these metrics, the most pronounced changes were found during March, which is consistent with increasing temperatures that are cited as a leading cause.

This study used dynamically downscaled reanalysis and climate model simulations to explore historical (1981-2010) and projected (2031-60) distributions of the meteorological variables (e.g., temperature, precipitation, and snowfall) relevant to the aforementioned issues facing southeast Alaska. Downscaling was necessary to help resolve the extreme topographical gradients and coastlines that are characteristic of the region. At daily 4-km spatial resolution it also reduced the number of parameterizations that were required for modeling certain physical processes (e.g., cumulus convection). These new dynamically downscaled data represent the current state of the art for southeast Alaska in terms of spatiotemporal resolution and period of record.

The benefits of dynamical downscaling as an improvement from coarser-scale global models in this region have been well documented. Bieniek et al. (2016) dynamically downscaled the ERA-Interim reanalysis (Dee et al. 2011) for Alaska at 20-km spatial resolution, generally finding better agreement with temperature and precipitation than with simulations using the coarser forcing data. Monaghan et al. (2018) downscaled the ERA-Interim for Alaska at 4-km resolution from 2002 to 2016 and found high correlations with observed temperature and precipitation. A brief summary of the questions that this research addressed for southeast Alaska is as follows:

1) How does dynamically downscaled reanalysis output of temperature and precipitation compare to station observations and station-based statistical products over a full 30-yr climate reference period?

2) How are the 30-yr distributions of temperature, precipitation and snowfall projected to change?

3) How are particular impacts-relevant climate extremes projected to change?

\section{Data and methods}

Regional dynamically downscaled climate model simulations were used to investigate historical (1981-2010) and projected (2031-60) climate states for southeast Alaska (Fig. 1). The original data for these simulations were provided from the Community Climate System Model, version 4 (CCSM), and Geophysical Fluid Dynamics Laboratory Climate Model, version 3 (GFDL; Donner et al. 2011), which are both members of phase 5 of the Coupled Model Intercomparison Project (CMIP5; Taylor et al. 2012). In an evaluation of near-surface temperature, precipitation, and sea level pressure among 21 CMIP5 models, these two routinely ranked in the top five for Alaska (Walsh et al. 2018b). Moreover, Flato et al. (2013, their Table 9.5) found that CCSM was at the low end and GFDL at the high end of climate sensitivity, which suggests that these two models provide a plausible range of outcomes. The downscaling was performed at 4-km spatial and hourly temporal resolution using the Weather Research and Forecasting (WRF) Model, version 4 (Skamarock et al. 2019). The original CCSM and GFDL spatial resolutions are approximately $0.94^{\circ} \times 1.25^{\circ}$ and $2^{\circ} \times 2.5^{\circ}$ (latitude $\times$ longitude), respectively. The projected simulations used the representative concentration pathway 

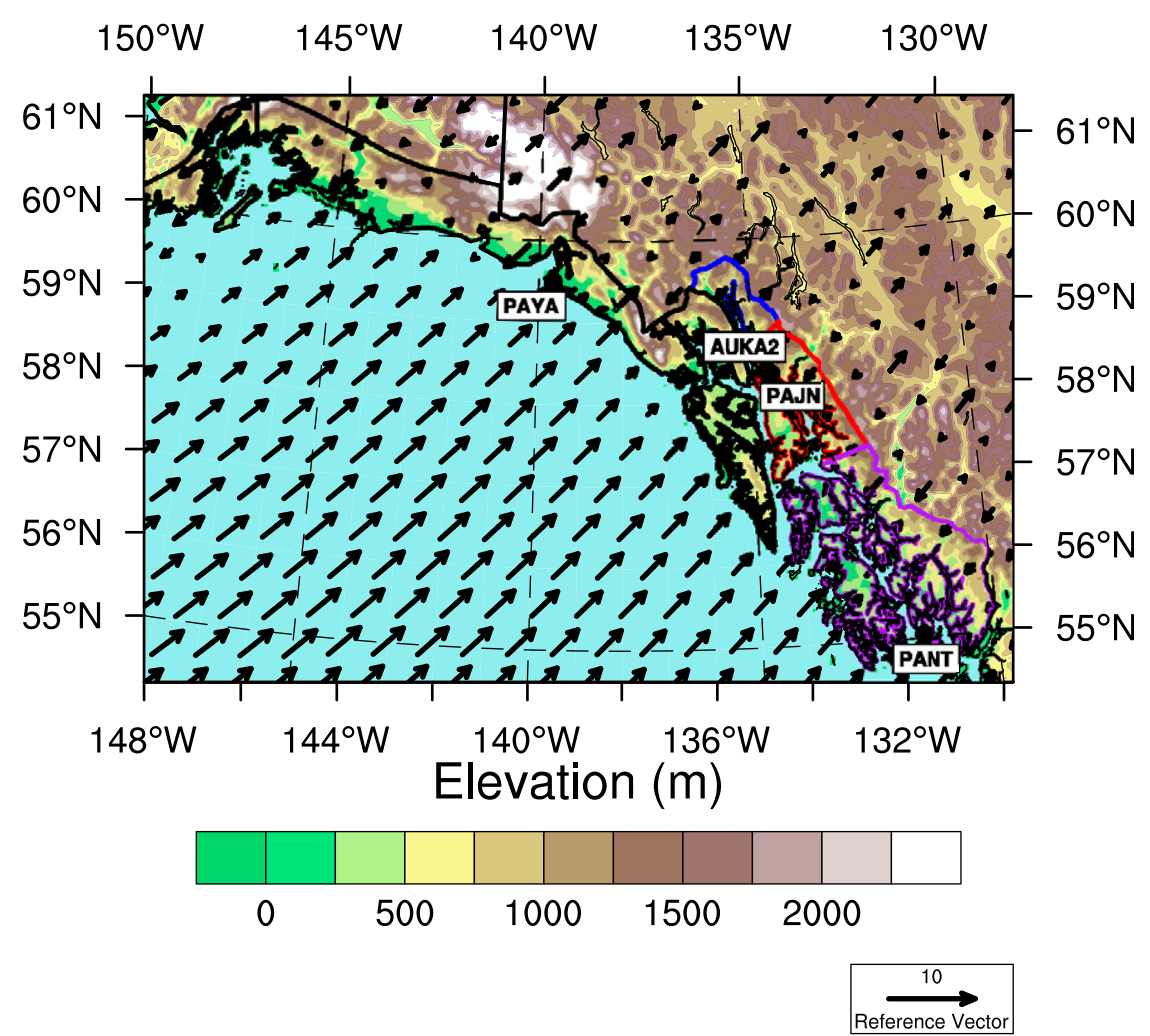

FIG. 1. Regional topography $(\mathrm{m})$ with Alaska climate divisions and station locations. The divisions include the Northeast Gulf (black border), North Panhandle (blue border), Central Panhandle (red border), and South Panhandle (purple border). The stations include Yakutat (PAYA), Auke Bay (AUKA2), Juneau (PAJN), and Annette (PANT). The climatological (1981-2010) 1000-hPa wind vectors $\left(\mathrm{m} \mathrm{s}^{-1}\right)$ from the downscaled CFSR are superimposed.

8.5 (RCP8.5; Riahi et al. 2011) emissions scenario, which was chosen because it best represented recent growth rates of global carbon dioxide emissions (Peters et al. 2013).

These climate model simulations were compared with the Climate Forecast System Reanalysis (CFSR; Saha et al. 2010), which was dynamically downscaled from 1981 to 2010 across southeast Alaska following the same procedure. The CFSR is a globally gridded weather forecast model with coupled atmosphere, land surface, sea ice, and ocean components that assimilate in situ and satellite observations to produce its forecasts. The original atmospheric model resolution of the CFSR is approximately $38 \mathrm{~km}$, and data are produced at an hourly time step. The CFSR is among the top-performing reanalysis models with respect to forecasting surface temperature and precipitation for southeast Alaska (Lader et al. 2016) and the Arctic (Lindsay et al. 2014).

Each of the downscaling simulations was conducted using a consistent method and set of input parameters. This included conducting 17 months of model spinup, beginning in August of the penultimate year before the start of the historical or projected period (i.e., August 1979 or August 2029) to properly build the spatial distribution of the ice fields across southeast Alaska. A continuous WRF simulation was then produced with each forcing dataset across the relevant time periods. The lateral boundary conditions for each domain were updated every $6 \mathrm{~h}$ using data from the forcing model to help constrain the simulations. At the 4-km spatial resolution WRF is able to resolve convective processes, and therefore, there was no need to parameterize cumulus convection. Other important physics options that were used in WRF include those for microphysics (Thompson et al. 2008), radiation [Rapid Radiative Transfer Model (RRTM); Iacono et al. 2008], boundary layer [Yonsei University (YSU); Hong et al. 2006], and surface physics (Noah-MP land surface model; Niu et al. 2011). Table 1 provides a more complete listing of the parameterization schemes used for the downscaling simulations.

Southeast Alaska has few long-term meteorological records available for comparison with the CFSR and the majority of these are at low elevations. Four stations were identified in the Global Historical Climatology Network-Daily database (GHCN-D; Menne et al. 2012) that contained at least $95 \%$ data coverage of temperature, precipitation, and snowfall over the historical period (1981-2010). These included (with their geographical coordinates, elevation above sea level, and station identifier listed) Annette $\left(55.04^{\circ} \mathrm{N}, 131.57^{\circ} \mathrm{W} ; 33 \mathrm{~m}\right.$; PANT), Auke Bay $\left(58.40^{\circ} \mathrm{N}, 134.66^{\circ} \mathrm{W} ; 13 \mathrm{~m}\right.$; AUKA2), Juneau $\left(58.36^{\circ} \mathrm{N}, 134.58^{\circ} \mathrm{W} ; 5 \mathrm{~m} ; \mathrm{PAJN}\right)$, and Yakutat $\left(59.50^{\circ} \mathrm{N}\right.$, $139.66^{\circ} \mathrm{W} ; 10 \mathrm{~m}$; PAYA). The CFSR was also compared 
TABLE 1. Selected WRF parameterization schemes used for the downscaling simulations.

\begin{tabular}{ll}
\hline \multicolumn{1}{c}{ Physics parameter } & Option name \\
\hline Microphysics (mp_physics) & Thompson \\
Cumulus (cu_physics) & Off \\
Longwave radiation (ra_lw_physics) & RRTMG \\
Shortwave radiation (ra_sw_physics) & RRTMG \\
Planetary boundary layer (bl_pbl_physics) & YSU \\
Surface layer (sf_sfclay_physics) & MM5 similarity \\
Lake (sf_lake_physics) & WRF-Lake \\
Surface (sf_surface_physics) & Noah-MP \\
Noah-MP parameters & \\
Dynamic vegetation (dveg) & Off \\
Stomatal resistance (opt_crs) & Ball-Berry \\
Surface-layer drag coefficient (opt_sfc) & Monin-Obukhov \\
Soil moisture factor for stomatal resistance (opt_btr) & Noah \\
Runoff and groundwater(opt_run) & Free drainage \\
Supercooled liquid water (opt_frz) & No iteration \\
Soil permeability (opt_inf) & Linear effect \\
Radiative transfer (opt_rad) & Two-stream \\
Ground surface albedo (opt_alb) & CLASS \\
Precipitation partitioning (opt_snf) & Jordan \\
Soil temperature lower boundary (opt_tbot) & Zero heat flux \\
Snow/soil temperature time scheme (opt_stc) & Semi-implicit \\
\hline
\end{tabular}

with data for the four southeast Alaska climate divisions, which are available from NOAA National Centers for Environmental Information's (NCEI) Climate at a Glance tool (https://www.ncdc.noaa.gov/cag/; NOAA National Centers for Environmental Information 2019). These divisions included the Northeast Gulf, North Panhandle, Central Panhandle, and South Panhandle (Fig. 1).

The projected climatologies result from a delta bias-correction method (Tabor and Williams 2010; Lader et al. 2017) wherein the individual climate models' historical and projected climatologies were differenced prior to adding to the CFSR:

$$
X_{\mathrm{BC}}(t)=O_{\mathrm{REF}}(t)+\left(\bar{X}_{\mathrm{RAW}, \mathrm{FUT}}-\bar{X}_{\mathrm{RAW}, \mathrm{REF}}\right),
$$

where $X_{\mathrm{BC}}(t)$ is the bias-corrected projection, $O_{\mathrm{REF}}(t)$ is the historical observed reference value (e.g., CFSR), and the $\bar{X}_{\mathrm{RAW}}$ values are the uncorrected climate model means for the future (FUT) and the historical reference (REF) periods. This procedure accounted for the bias inherent in each model, thereby producing bias-corrected projections. Any negative precipitation values were set to zero. The climate extremes indices that were used include the number of annual frost days (FD) when the daily minimum temperature was below freezing, and maximum consecutive 3-day precipitation (RX3) and maximum consecutive 3-day snowfall (SX3) amounts. These extremes indices were based on a standardized set for temperature and precipitation, described in Zhang et al. (2011), which were designed for comparison across different regions.

\section{Results}

\section{a. Temperature}

Historical (1981-2010) monthly average temperature observations, derived from GHCN-D data, for four stations in southeast Alaska were compared to the nearest grid cell to each station in the downscaled CFSR (Fig. 2). Each comparison included the calculation of three statistical error metrics: root-mean-square error (RMSE), mean-absolute error (MAE), and mean bias. The best agreement between the downscaled CFSR and station observations was for Annette (Fig. 2a), where the RMSE was $0.77^{\circ} \mathrm{C}$ and the MAE was $0.65^{\circ} \mathrm{C}$; the worst agreement was for Auke Bay (Fig. 2b), where these values were $1.40^{\circ}$ and $1.21^{\circ} \mathrm{C}$, respectively. The lowest bias was for Juneau $\left(0.04^{\circ} \mathrm{C}\right.$; Fig. $\left.2 \mathrm{c}\right)$; however, the MAE here $\left(0.79^{\circ} \mathrm{C}\right)$ was greater than for Annette, which indicates that the low bias resulted from the cancellation of positive and negative differences. There was generally a reduction of RMSE when using an adjacent grid cell with an elevation that more closely matched the actual station elevation (not shown). The nearest grid cell to Juneau had an elevation of $105 \mathrm{~m}$, but the station was at $5 \mathrm{~m}$; using the adjacent grid cell closest to the actual elevation $(48 \mathrm{~m})$, lowered the RMSE from $1.05^{\circ}$ to $0.94^{\circ} \mathrm{C}$.

There was a tendency for the CFSR data to exhibit a warm bias for the colder parts of the temperature distributions and a cold bias for the warmer ones (Fig. 2). This was also visible in the comparison of monthly temperature data between the four southeast Alaska climate divisions from NCEI and the average values over these same regions from the CFSR (Fig. 3). Agreement between the two datasets was best for the South Panhandle division (Fig. 3d), which includes Annette, where the CFSR had the best agreement with station observations (Fig. 2a). The root-mean-square difference (RMSD) and mean absolute deviation (MAD) for this division were $0.83^{\circ}$ and $0.69^{\circ} \mathrm{C}$, respectively. The worst relationship was for the North Panhandle (Fig. 3b) with RMSD of $1.40^{\circ} \mathrm{C}$ and MAD of $1.23^{\circ} \mathrm{C}$. The word "difference" was used here rather than "error" because the downscaled CFSR and NCEI Climate at a Glance datasets are both products that are based on past observations, 


\section{(a) Annette}

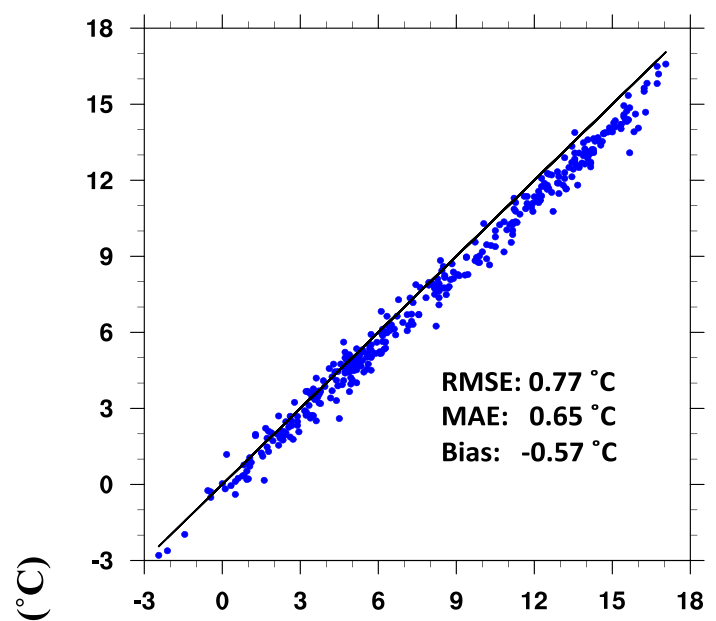

(c) Juneau

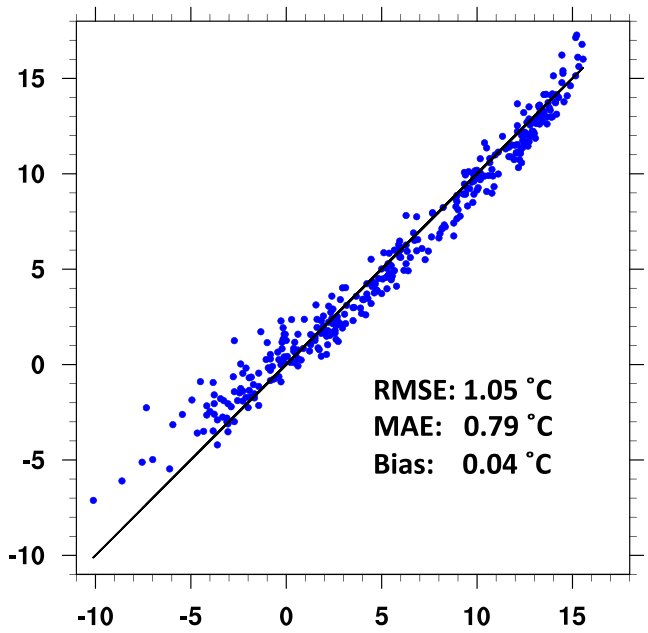

(b) Auke Bay

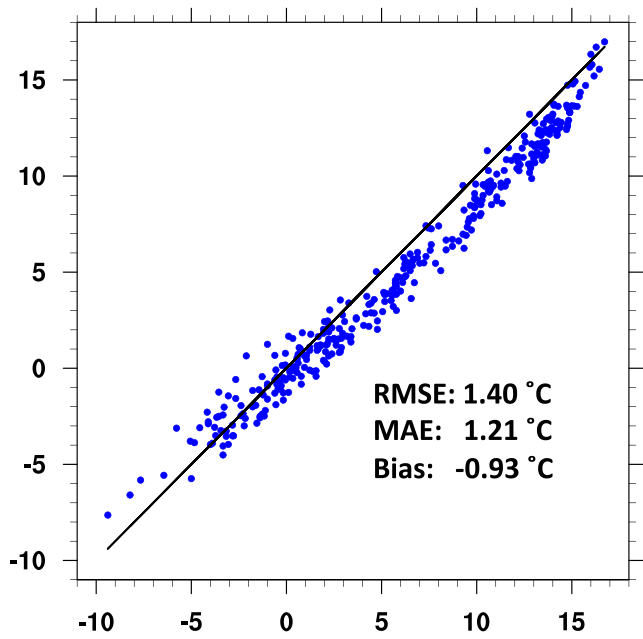

(d) Yakutat

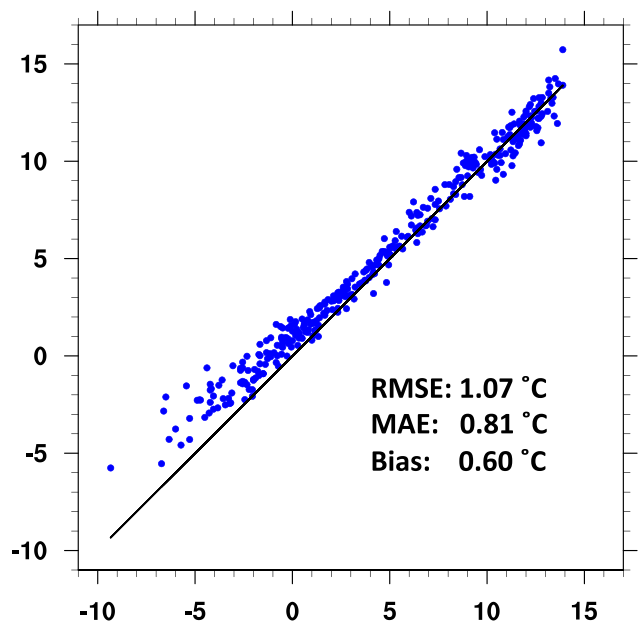

Observed T2 $\left({ }^{\circ} \mathrm{C}\right)$

FIG. 2. Monthly 2-m temperature (T2; ${ }^{\circ} \mathrm{C}$ ) from 1981 to 2010 at (a) Annette, (b) Auke Bay, (c) Juneau, and (d) Yakutat. Station observations ( $x$ axis) are compared with the nearest grid cell to each station from the downscaled CFSR ( $y$ axis). The RMSE, MAE, and bias error statistics are provided.

but the former was produced via dynamical downscaling and the latter by a statistical interpolation algorithm. Each dataset has its strengths and weaknesses, and these depend on the intended purpose of the data user.

The seasonal 2-m temperature climatologies from the historical CFSR (1981-2010) and bias-corrected climate model projections (2031-60) for southeast Alaska are shown in Fig. 4. Both models show warming for every meteorological season [e.g., winter (DJF), spring (MAM), summer (JJA), and autumn (SON)]. The greatest seasonal change from the CCSM was for $\mathrm{SON}$, which warmed $2.12^{\circ} \mathrm{C}$; from the GFDL the largest change was for JJA, which warmed $3.28^{\circ} \mathrm{C}$. The smallest warming from CCSM was during MAM at $1.12^{\circ} \mathrm{C}$, and in SON $\left(1.87^{\circ} \mathrm{C}\right)$ according to the GFDL. Most of the seasonal warming was close to $2^{\circ} \mathrm{C}$, but with the noted exceptions above. Annual temperatures are projected to increase by $1.82^{\circ} \mathrm{C}$ (CCSM) and $2.32^{\circ} \mathrm{C}$ (GFDL) (Table 2).

Coincident with this warming was a substantial decrease in the frequency of frost days (i.e., days with a minimum temperature below freezing). The CFSR had an average number of FD per year across southeast Alaska of 166.91; the historical CCSM (164.93) and GFDL (178.68) bracketed the CFSR and show spatial agreement (Fig. 5, top row). Projections from both models indicated an average decrease of more than one month of these days annually (Fig. 5, bottom row). The GFDL had a greater decrease (37.61 days per year) than the CCSM (32.45 days per year). There were no locations from either climate model where the number of frost days was projected to increase. 
(a) Northeast Gulf

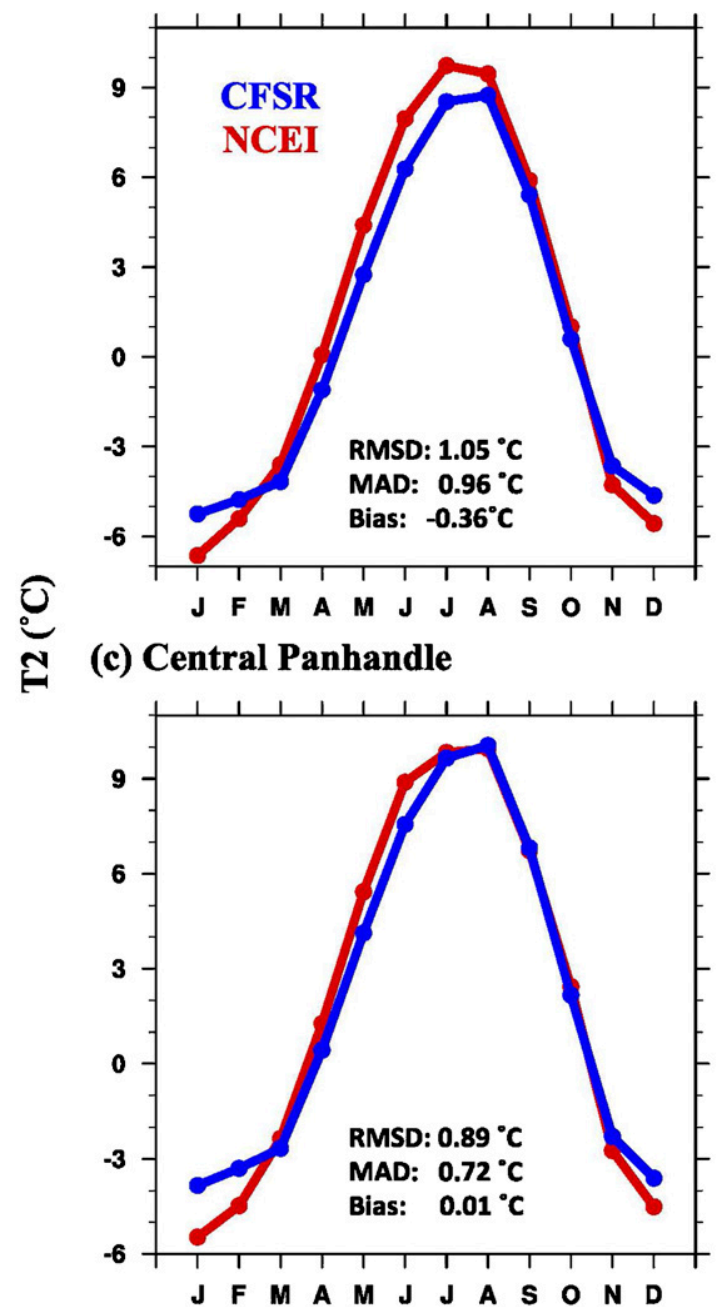

(b) North Panhandle

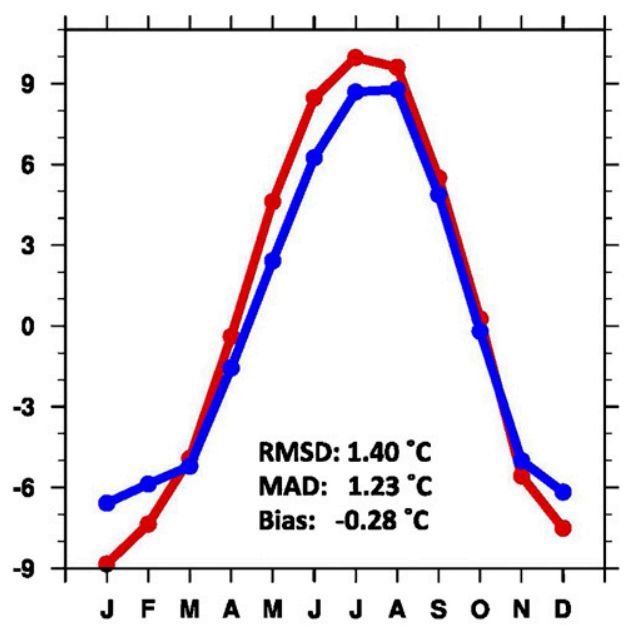

(d) South Panhandle

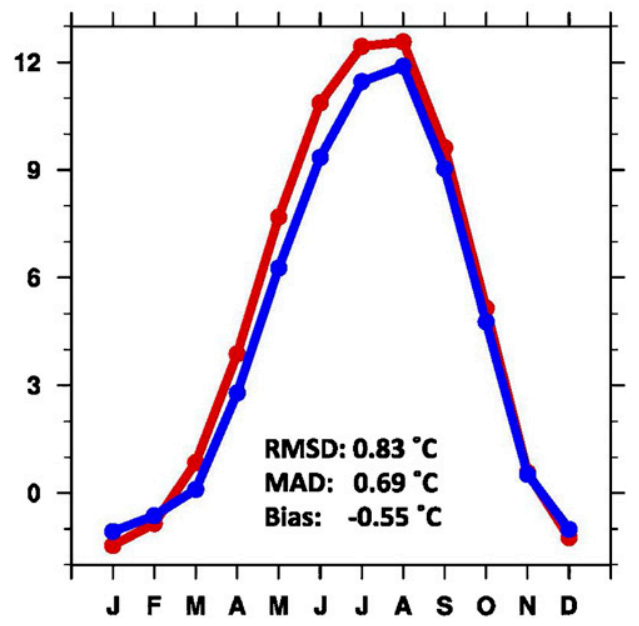

FIG. 3. Monthly average T2 $\left({ }^{\circ} \mathrm{C}\right.$ ) from 1981 to 2010 for (a) Northeast Gulf, (b) North Panhandle, (c) Central Panhandle, and (d) South Panhandle. Alaska climate division data (NCEI; red) are compared with the gridcell average for each division from the downscaled CFSR (blue). The RMSE, MAE, and bias error statistics are provided.

\section{b. Precipitation}

Historical (1981-2010) monthly total precipitation (PCPT) observations, also derived from GHCN-D data, for four stations in southeast Alaska were compared to the nearest grid cell to each station in the downscaled CFSR (Fig. 6). The closest agreement was for Auke Bay (Fig. 6b) with RMSE of $6.02 \mathrm{~cm}$ and MAE of $4.58 \mathrm{~cm}$ and the poorest relationship was for Yakutat (Fig. 6d) with values of 14.23 and $10.09 \mathrm{~cm}$, respectively. The downscaled CFSR bias at the four stations was mixed; the nearest grid cells to Juneau and Auke Bay had positive precipitation bias, but the bias for Annette and Yakutat were negative. The bias for both Juneau and Yakutat was within $0.30 \mathrm{~cm}$ of the MAE, which indicates that the error at each location was largely in one direction. At Juneau, where the adjacent grid cells surrounding the nearest grid cell to the station had elevations that ranged from 48 to $442 \mathrm{~m}$, selection of the lower elevation cells (i.e., closer to the Juneau station elevation) substantially reduced the RMSE from 11.11 to $7.39 \mathrm{~cm}$. This was not true for Yakutat, however, where the adjacent grid cells ranged from 0 to $24 \mathrm{~m}$ (not shown). Here, the appropriate magnitudes were not realized near the coast, but rather farther inland where elevations were also much higher.

A comparison of monthly precipitation data between the four southeast Alaska climate divisions from NCEI and the average values over these same regions from the downscaled CFSR (Fig. 7) showed close agreement for the North Panhandle (RMSE: $1.34 \mathrm{~cm}$; Fig. 7b), but a systemic negative bias for the other three. Unlike with the temperature analyses however, there was not always consistency between the station comparisons and the climate division comparisons. The CFSR was too dry relative to the NCEI product for the Central Panhandle 

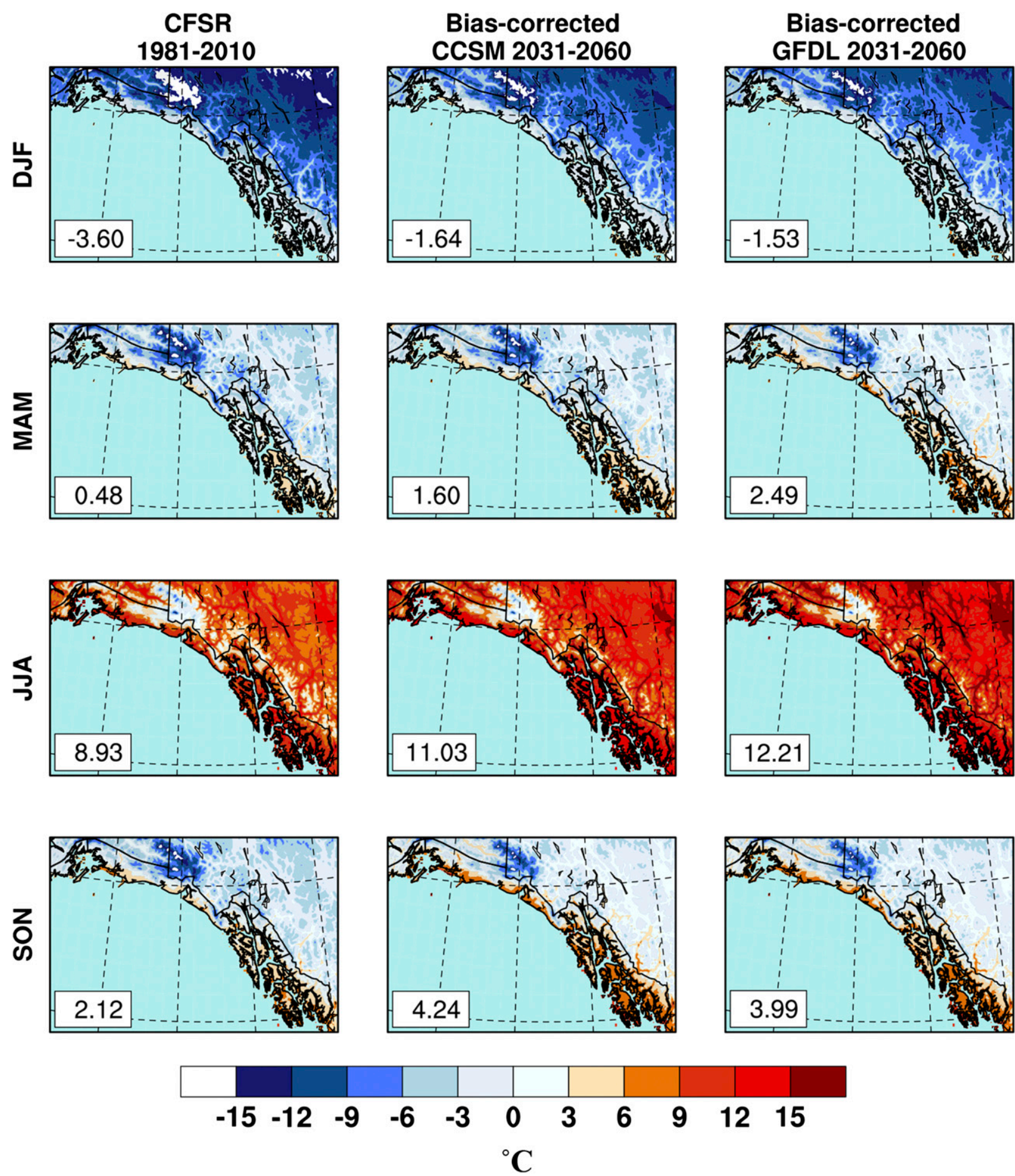

FIG. 4. Seasonal T2 $\left({ }^{\circ} \mathrm{C}\right)$ climatologies from (left) CFSR (1981-2010), (center) CCSM bias-corrected projections (2031-60 minus 19812010) added to CFSR, and (right) GFDL bias-corrected projections (2031-60 minus 1981-2010) added to CFSR. The aggregated gridcell average over the four southeast Alaska climate divisions is shown in the bottom left of each map.

(Fig. 7c), but the nearest grid cells to Auke Bay (Fig. 6b) and Juneau (Fig. 6c) - both of which are in this region-were too wet. A plausible reason for these differences will be explained in section 4.
The historical (1981-2010) seasonal CFSR precipitation climatology across southeast Alaska (Fig. 8, left) showed that SON was the wettest and JJA was the driest. Future biascorrected projections (2031-60) from the CCSM indicated 
TABLE 2. Climatological 2-m temperature (T2), PCPT, and accumulated snowfall (ACSNOW) averaged across the southeast Alaska land grid cells from the downscaled simulations $(n=7171)$. Trends were calculated using the Theil-Sen estimator, and statistical significance was assessed using the Mann-Kendall nonparametric test. Significant trends $(p<0.05)$ are in boldface font. The relative projected changes from each climate model are indicated by italics.

\begin{tabular}{|c|c|c|c|c|c|c|}
\hline & \multicolumn{2}{|r|}{$\mathrm{T} 2$} & \multicolumn{2}{|c|}{ PCPT } & \multicolumn{2}{|c|}{ ACSNOW } \\
\hline & Mean $\left({ }^{\circ} \mathrm{C}\right)$ & Trend $\left({ }^{\circ} \mathrm{C}\right.$ decade $\left.{ }^{-1}\right)$ & Mean $(\mathrm{cm})$ & Trend $\left(\mathrm{cm} \mathrm{decade}{ }^{-1}\right)$ & Mean $(\mathrm{cm})$ & Trend $\left(\mathrm{cm} \mathrm{decade}{ }^{-1}\right)$ \\
\hline & \multicolumn{6}{|c|}{ Historical (1981-2010) } \\
\hline CFSR & 2.01 & 0.03 & 312.32 & -6.64 & 107.06 & -0.93 \\
\hline CCSM & 1.99 & 0.27 & 342.40 & -25.94 & 175.47 & $-\mathbf{1 5 . 8 6}$ \\
\hline \multirow[t]{2}{*}{ GFDL } & 1.32 & 0.36 & 361.04 & -31.66 & 162.45 & 0.64 \\
\hline & \multicolumn{6}{|c|}{ Projected $(2031-60)$} \\
\hline CCSM & $3.81(+1.82)$ & 0.47 & $363.69(+21.29)$ & -3.10 & $144.98(-30.49)$ & -9.83 \\
\hline GFDL & $3.64(+2.32)$ & 0.85 & $373.10(+12.06)$ & -13.54 & $124.44(-38.01)$ & -2.60 \\
\hline
\end{tabular}

increased precipitation for all seasons except for JJA, which showed a decrease of $-0.31 \mathrm{~cm}$; the greatest increase $(13.82 \mathrm{~cm})$ was for SON. The GFDL projected precipitation to increase during DJF and SON, with increases of 10.88 and $4.26 \mathrm{~cm}$, respectively, but decreases of $2.77 \mathrm{~cm}$ during MAM and $0.30 \mathrm{~cm}$ during JJA. Thus, both models showed increased precipitation during the wettest seasons; however, they both also indicated a slight drying during the summer, which, coupled with increased
CFSR 1981-2010

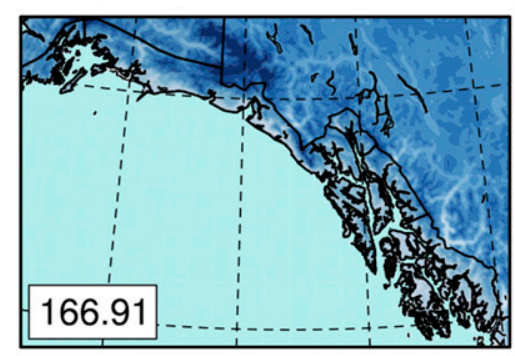

CCSM 1981-2010

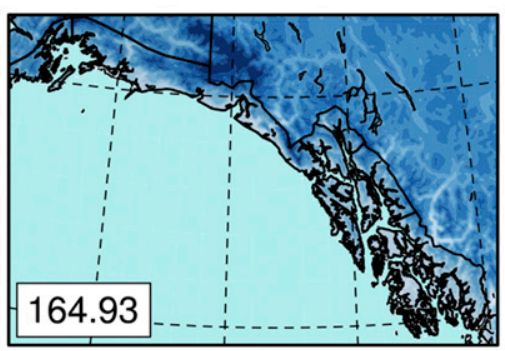

GFDL 1981-2010

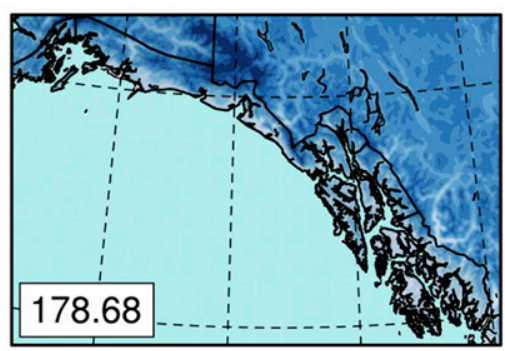

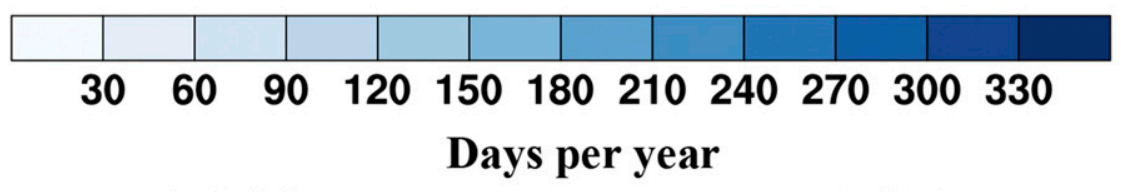

$\Delta$ CCSM

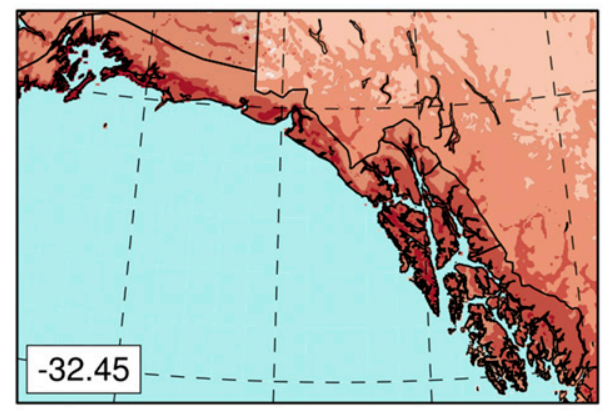

$\triangle$ GFDL

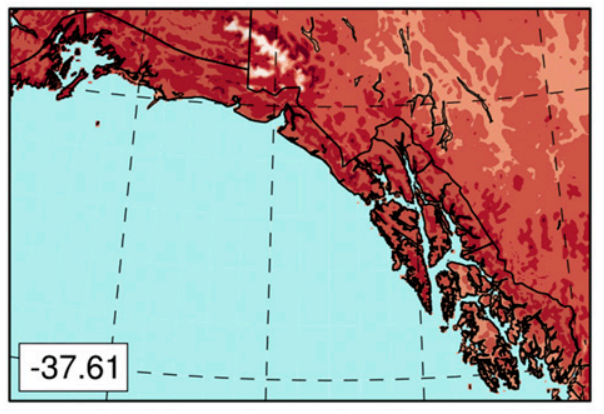

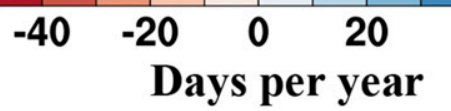

FIG. 5. Annual historical (1981-2010) climatologies of frost days from (top left) CFSR, (top center) CCSM, and (top right) GFDL. Also shown are (bottom) projected changes for each climate model (2031-60), relative to their historical period. The aggregated gridcell average (days) over the four southeast Alaska climate divisions is shown in the bottom left of each map. 
(a) Annette

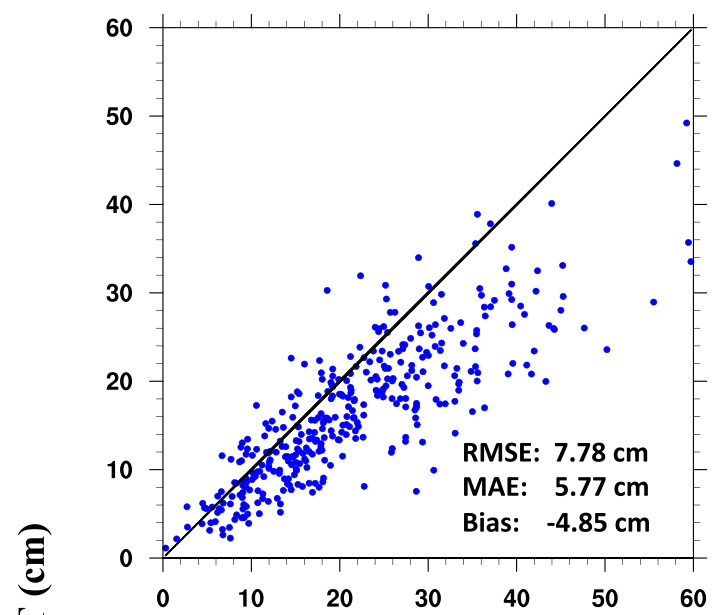

(c) Juneau

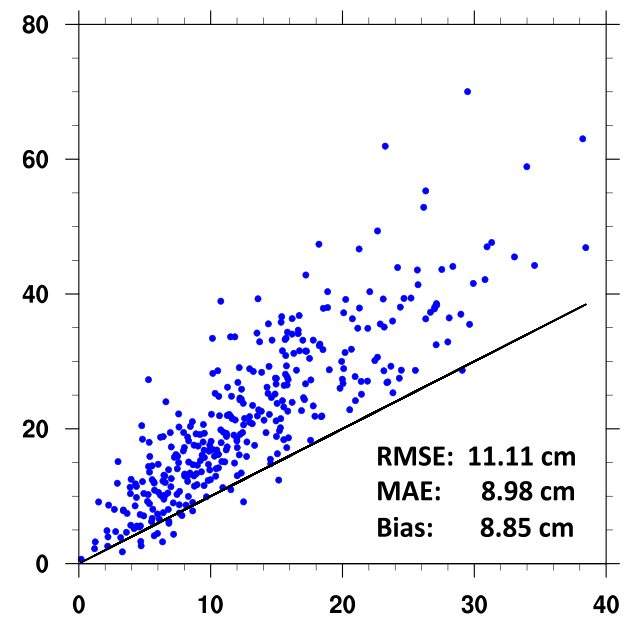

(b) Auke Bay

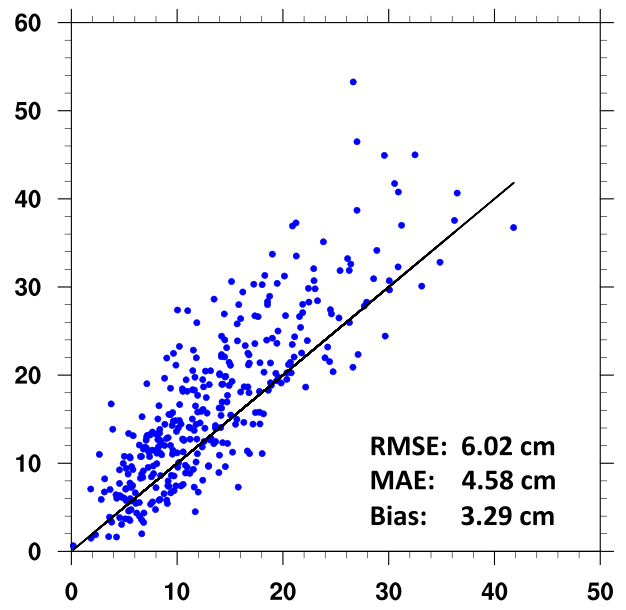

(d) Yakutat

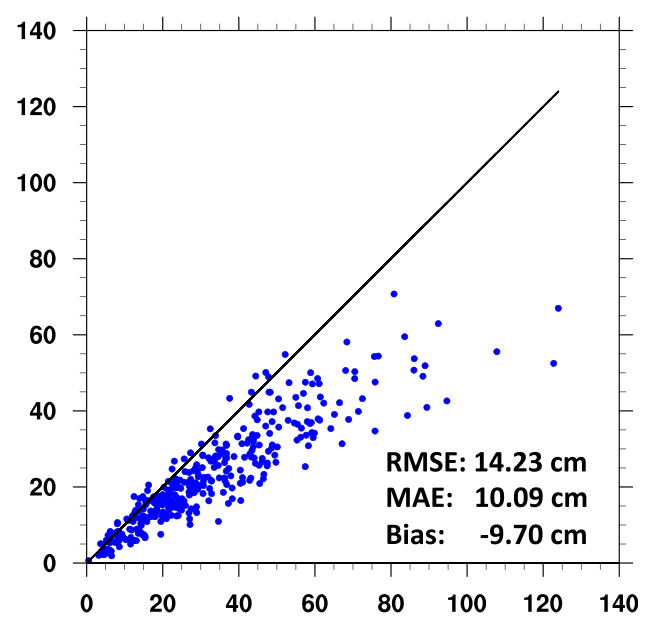

\section{Observed PCPT (cm)}

FIG. 6. As in Fig. 2, but for precipitation (PCPT; cm).

temperatures, would lead to a moisture deficit relative to the historical period. Annual precipitation was projected to increase by $21.29 \mathrm{~cm}$ (CCSM) and $12.06 \mathrm{~cm}$ (GFDL) (Table 2), although the trend within the future $30-\mathrm{yr}$ time interval was negative in each model. The negative $30-\mathrm{yr}$ trends point to the important role of internal variability.

Despite seasonal differences in the projection of total precipitation change, the direction of change of extreme precipitation (i.e., increasing) was clearer. The CFSR had an annual average maximum consecutive 3-day precipitation amount of $18.31 \mathrm{~cm}$ across southeast Alaska; the historical climate models were wetter than the CFSR with amounts of 21.62 and $21.18 \mathrm{~cm}$ for CCSM and GFDL, respectively (Fig. 9, top row). The CCSM projected an average increase of $2.35 \mathrm{~cm}$ for this metric, relative to the historical period, and the GFDL was wetter, showing an increase of $3.49 \mathrm{~cm}$ (Fig. 9, bottom row). The largest increases were in the Northeast Gulf region near Yakutat. Yet, there were areas, particularly in the South Panhandle, where slight decreases (i.e., $\leq 1.50 \mathrm{~cm}$ ) were projected.

\section{c. Snowfall}

The historical (1981-2010) CFSR seasonal snowfall climatology, measured in terms of liquid water equivalent for southeast Alaska (Fig. 10) showed the greatest amounts occurred in DJF $(50.36 \mathrm{~cm})$; comparable amounts of 27.23 and $27.64 \mathrm{~cm}$ fell during MAM and SON, respectively. Both climate models projected snowfall to decrease for all seasons with the largest magnitude decreases in SON. The projected MAM decreases were considerably smaller, such that during the projected period, spring clearly becomes the second snowiest season, behind DJF. The greatest relative snowfall decreases occurred during JJA, shrinking from a historical gridcell average of $1.83 \mathrm{~cm}$ to between 0.13 and $0.64 \mathrm{~cm}$ from the GFDL and CCSM, respectively. The GFDL produced larger decreases than the 


\section{(a) Northeast Gulf}

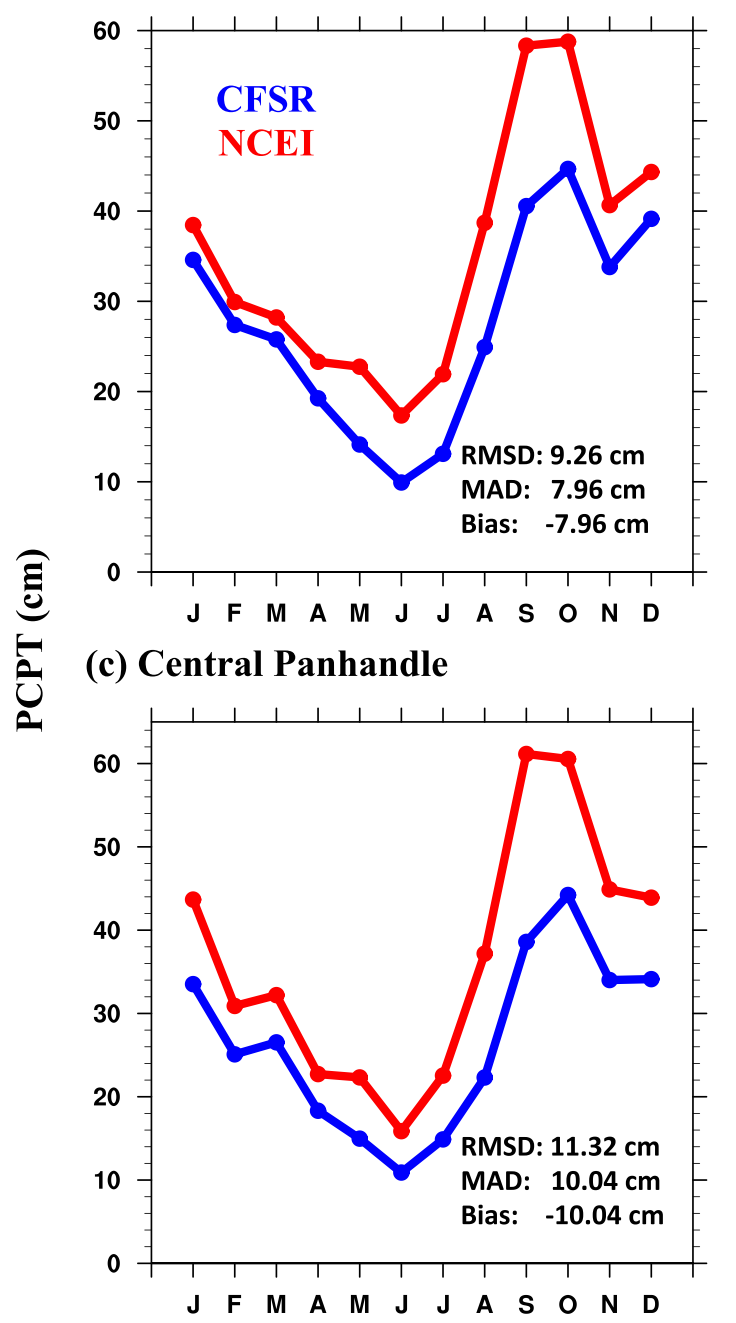

(b) North Panhandle

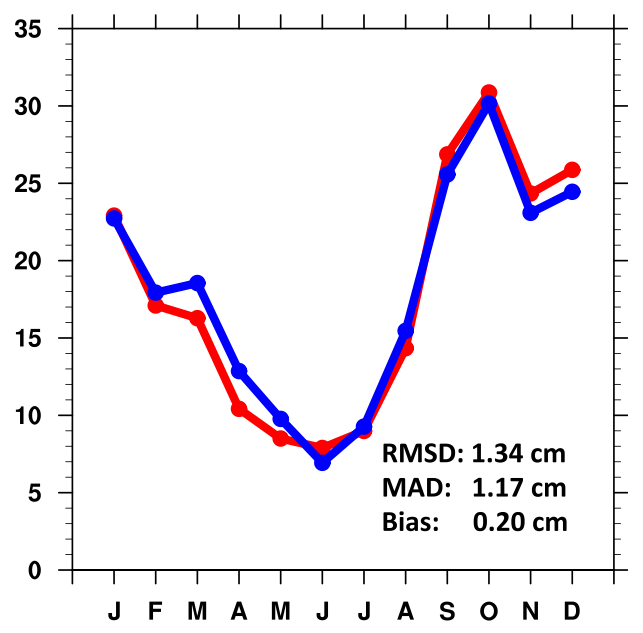

(d) South Panhandle

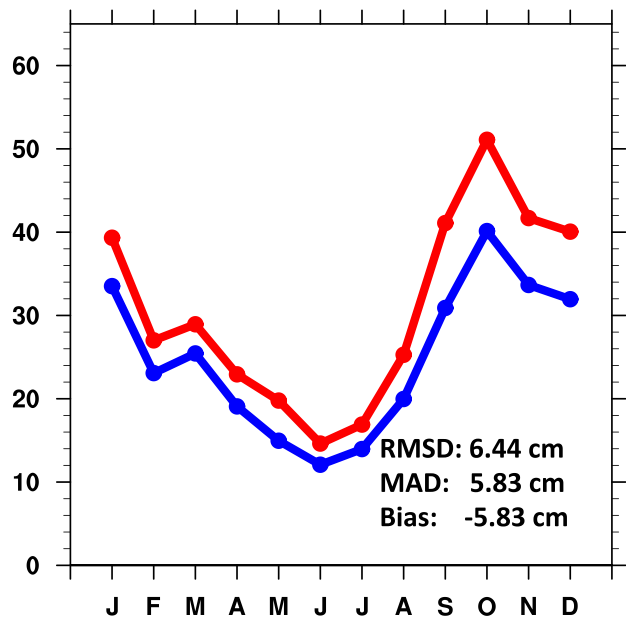

FIG. 7. As in Fig. 3, but for PCPT (cm).

CCSM for all seasons except DJF. Annual snowfall was projected to decrease by $30.49 \mathrm{~cm}$ (CCSM) and $38.01 \mathrm{~cm}$ (GFDL) (Table 2).

The annual average maximum consecutive 3-day snowfall amount across southeast Alaska from the CFSR was $8.88 \mathrm{~cm}$; the historical climate models were snowier at 12.63 and $11.33 \mathrm{~cm}$ from CCSM and GFDL, respectively (Fig. 11, top row). Projections of this extreme snowfall metric showed decreases, on average, of $1.40 \mathrm{~cm}$ for CCSM and $0.52 \mathrm{~cm}$ for GFDL (Fig. 11, bottom row). These projected changes are in contrast to those of the extreme precipitation metric in Fig. 8, which largely showed increasing amounts. However, the projected extreme snowfall changes were not uniform in their spatial extent; the direction of these changes largely depended on elevation and latitude. High-elevation locations, particularly in the Northeast Gulf climate division, were projected to have increased extreme snowfall amounts. Meanwhile, lowelevation coastal and more southerly locations were projected to have lower extreme snowfall amounts.

\section{Discussion}

The projected changes in temperature were consistent with historical trends in Table 2. The CCSM had a trend of $0.27^{\circ} \mathrm{C} \mathrm{decade}^{-1}$, which when multiplied by 5 decades (i.e., the difference between the two periods of study), would yield an increase of $1.35^{\circ} \mathrm{C}$. The projected change was larger at $1.82^{\circ} \mathrm{C}$. Similarly, the GFDL's trend of $0.36^{\circ} \mathrm{Cdecade}^{-1}$, would yield an increase of $1.80^{\circ} \mathrm{C}$, compared to the projected increase of $2.32^{\circ} \mathrm{C}$. Both models indicate an increasing rate over time. The downscaled CFSR provides an example of the need to exercise caution when discussing trends over short $(30 \mathrm{yr})$ periods. The downscaled CFSR's trend was $0.03^{\circ} \mathrm{C}_{\text {decade }}{ }^{-1}$ when considering $1981-2010$ but was $0.28^{\circ} \mathrm{C} \mathrm{decade}^{-1}$ when considering the last 30 years (1990-2019; not shown) because the 1980s was a warm decade. Similarly, all of the models had negative precipitation trends (sometimes significant) during the historical period, but both climate models showed a projected net increase in precipitation between the two periods. Recall from the introduction section that precipitation trends across southeast 

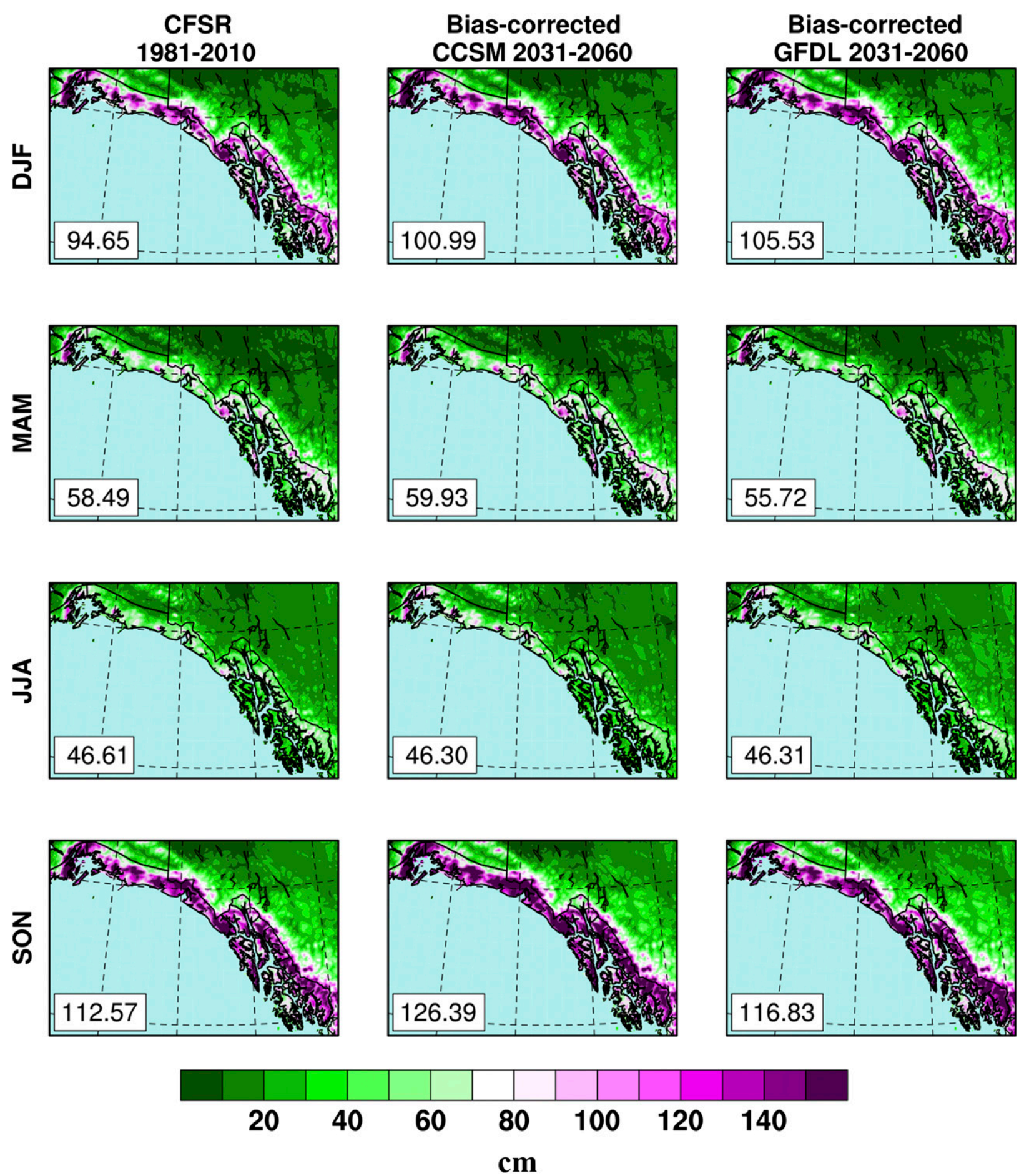

FIG. 8. As in Fig. 4, but for PCPT (cm).

Alaska over a recent 50-yr period (1969-2018) were positive (Thoman and Walsh 2019). This shows again how internal variability can predominate in 30-yr trends.

The downscaled CFSR showed varying levels of agreement between individual grid cells and station observations. A plausible reason for the differences at the station (gridpoint) level resides with the downscaled CFSR's handling of vertical motion at the ocean-land interface. The 1000-hPa climatological wind vectors (Fig. 1) illustrate the general flow pattern of the region. At Yakutat, where the downscaled CFSR is too dry (Fig. 6d), there is no barrier between the station and the ocean, and it is possible that the $4-\mathrm{km}$ grid resolution is still too 
CFSR 1981-2010

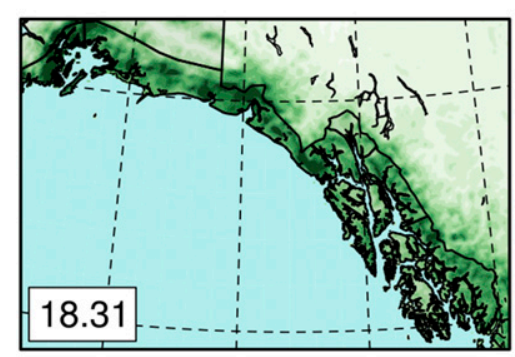

CCSM 1981-2010

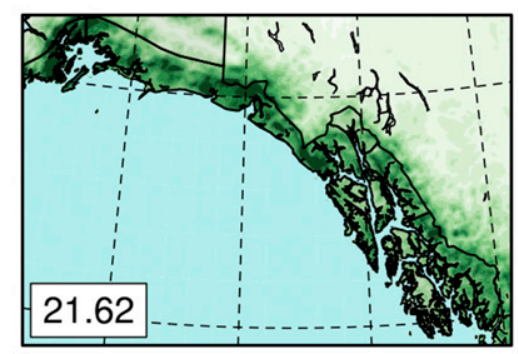

GFDL 1981-2010

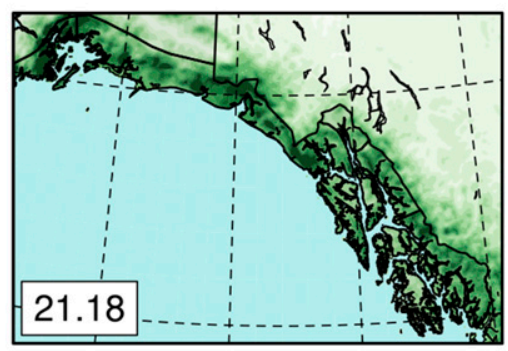

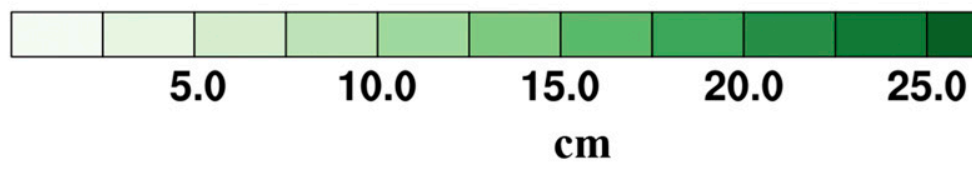

$\Delta$ CCSM

$\Delta$ GFDL
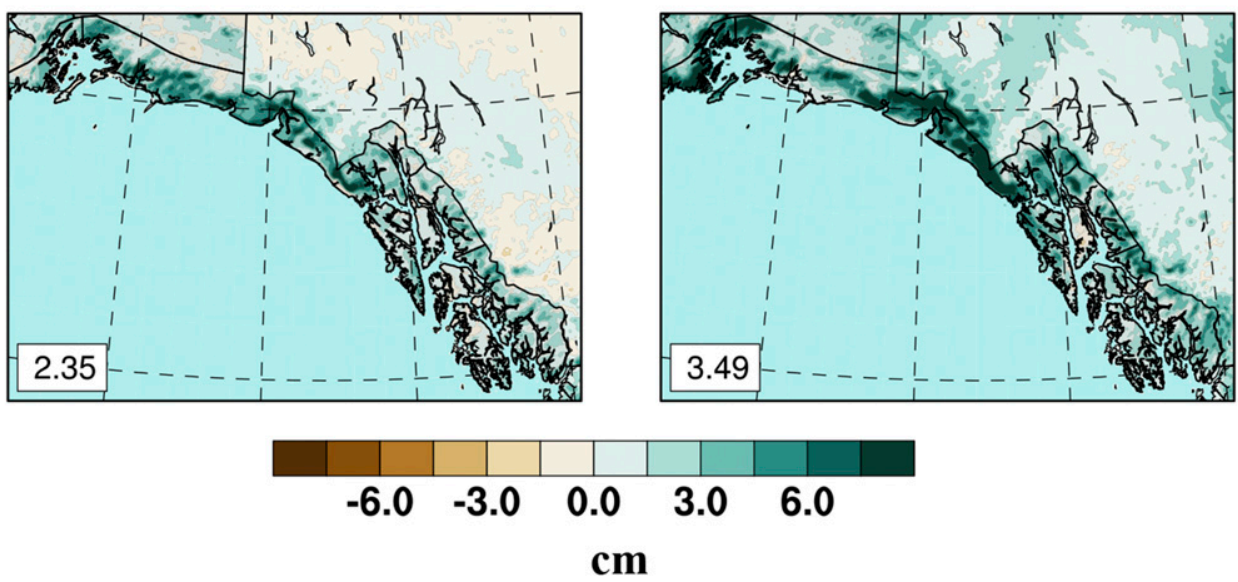

FIG. 9. As in Fig. 5, but for maximum 3-day precipitation $(\mathrm{cm})$.

coarse to resolve the abrupt change in topography and hence to capture the full magnitude of the upward motion. At Juneau and Auke Bay, however, the prevailing flow crosses outer islands first and would begin to ascend in the model prior to reaching these stations. The model would also be too coarse to pick up much of any downsloping between the islands, which could account for it being too wet.

At the climate division scale, the discrepancy between the monthly climatological time series of precipitation from the downscaled CFSR and the NCEI product (Fig. 7) appears to stem from the location of the stations ingested into the latter. The majority of these stations are on the ocean side of the coastal ridgeline that transects the region (see Vose et al. 2017, Fig. 1) and these areas receive substantially more precipitation than on the continental side. The climate division that is least affected by this issue is the North Panhandle because it is less exposed to the immediate coastline; here, the agreement between the CFSR and the NCEI product is remarkably good (Fig. 7b).

The agreement of temperature between the downscaled CFSR and the NCEI products was greater than it was for precipitation. The largest differences were in winter when the NCEI values were colder than the CFSR (Fig. 3). This also appears directly related to the stations that were assimilated into the NCEI product, which, on average, were at a lower elevation than the mean elevation of the CFSR grid cells in each division. The CFSR assimilates satellite radiances and radiosonde data, but not station observations of 2-m temperature to produce its temperature fields. The coldest monthly temperatures at low elevations occur when near-surface temperature inversions are present, and these are common during winter even in coastal locations across Alaska (Bourne et al. 2010). This is consistent with the station comparisons for Auke Bay, Juneau, and Yakutat (Figs. 2b-d) where the CFSR grid cells used were at a slightly higher elevation than the stations themselves. In summer, when the environmental lapse rate is more standard (i.e., temperatures cool with height) the CFSR was colder than NCEI in the divisional analyses (Fig. 3).

Seasonal temperatures were projected to warm by approximately $2^{\circ} \mathrm{C}$ in most seasons according to both climate models (Fig. 4); however, this relatively uniform warming would differentially impact the future seasonality of snowfall across 

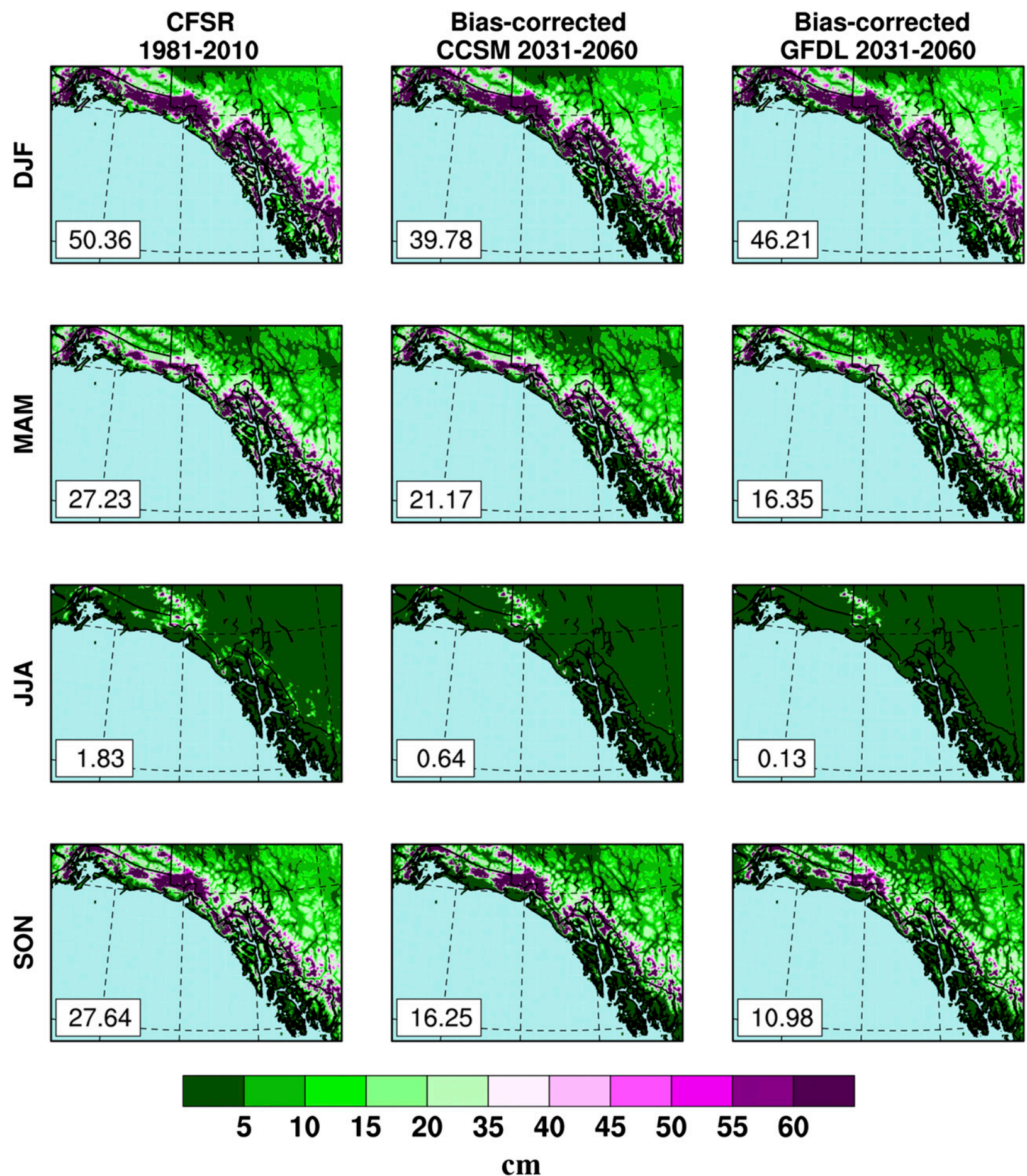

FIG. 10. As in Fig. 4, but for snowfall (cm).

southeast Alaska. The largest percent change of seasonal snowfall (excluding summer) occurred in autumn with decreases of $41.2 \%$ and $60.3 \%$ from CCSM and GFDL, respectively. Projected decreases during winter were $8.2 \%$ for CCSM and $21.0 \%$ for GFDL. These changes make sense given that mean winter temperatures are projected to remain below freezing, while spring and autumn temperatures, which were already slightly above freezing, warm even farther above this critical threshold. This contraction of the snow season is supported by the greater than one-month decrease in the annual number of frost days (Fig. 5), which is also consistent with prior research (Lader et al. 2017). 
CFSR 1981-2010

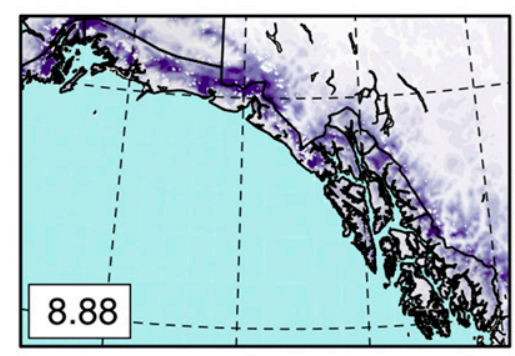

CCSM 1981-2010

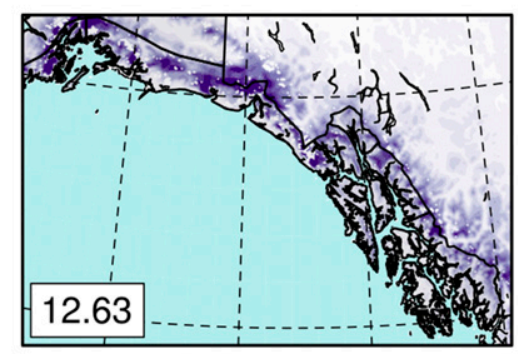

GFDL 1981-2010

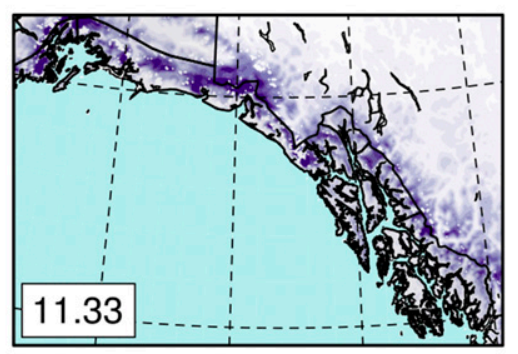

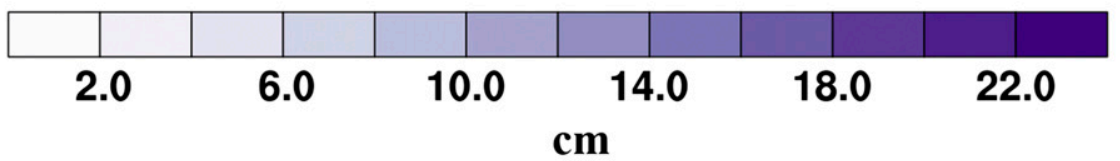

$\Delta$ CCSM

$\Delta$ GFDL
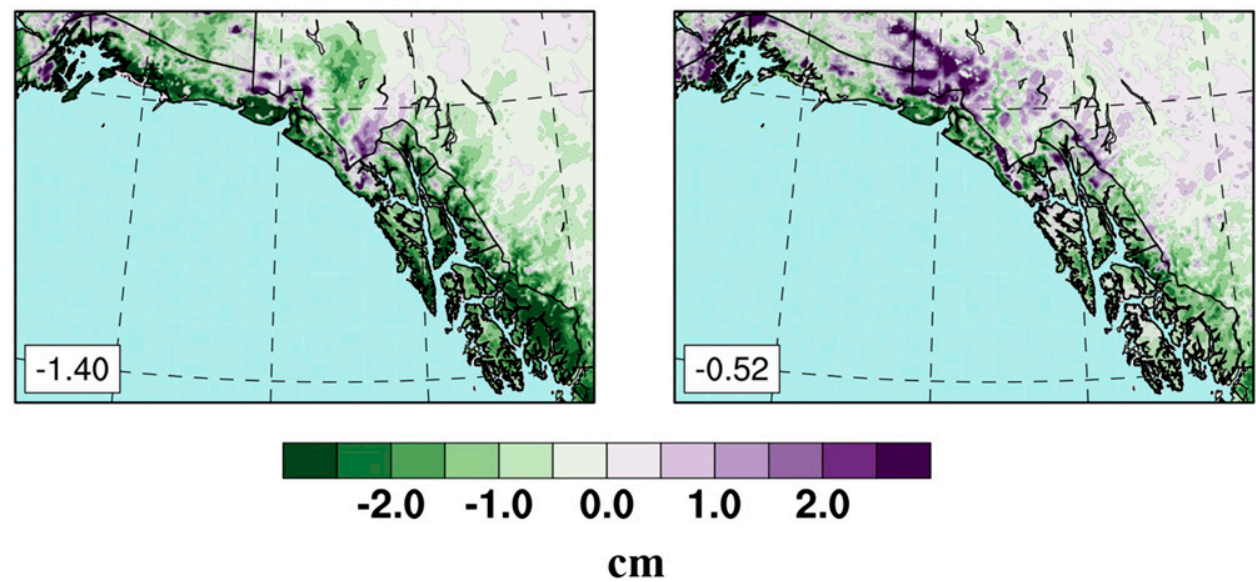

FIG. 11. As in Fig. 5, but for maximum 3-day snowfall (cm).

The impact to snowfall of projected regional warming also depended on elevation with higher locations experiencing a smaller decrease than lower ones. When restricting the sample area to only grid cells above $1000 \mathrm{~m}$ ( $\sim 23 \%$ of southeast Alaska), both the CCSM and GFDL showed slight increases in winter snowfall; GFDL also indicated an average increase of $0.73 \mathrm{~cm}$ in the maximum consecutive 3-day snowfall amount. At these elevations, autumn continues to be the second snowiest season, behind winter, but amounts are much closer to those of spring by 2031-60. A statewide analysis of annual snowfall projections out to 2100 found decreases of $40.6 \%-41.3 \%$ for areas below $1000 \mathrm{~m}$ and decreases of only $13.5 \%-14.2 \%$ above (Lader et al. 2020). These discrepancies appear to be related to temperature. Above $1000 \mathrm{~m}$, both models show that temperatures warm more by 2031-60 than they do at lower elevations during winter and autumn, but above $1000 \mathrm{~m}$ temperatures remain well below freezing, whereas the average temperature at or below $1000 \mathrm{~m}$ rises above freezing. Previous research has identified mechanisms for this amplified warming with height (Diaz et al. 2014; Pepin et al. 2015) and these seasonal differences implicate the snow-albedo feedback as a plausible driver. More generally, as seasonal temperatures increase above freezing, the rain/snow line is expected to recede to the north, and the magnitude of these shifts depends on the emissions scenario that is followed (Ning and Bradley 2015).

Despite the snowfall decreases that are projected for most areas during winter and autumn, total precipitation is anticipated to increase. Winter precipitation increases ranged from $6.7 \%$ to $11.5 \%$ for CCSM and GFDL, respectively; autumn increases were $12.3 \%$ for CCSM and $3.8 \%$ for GFDL. One might hypothesize that these increases are related to future changes to the predominant large-scale atmospheric flow. The Aleutian low, which is present during winter due to the thermal contrast between land and ocean temperatures, is expected to deepen and expand northward under globally warming temperatures and these changes would increase the moisture flux into southeast Alaska (Gan et al. 2017). A separate analysis of extreme near-surface winds associated with winter cyclones found a projected displacement northeastward into the Gulf of Alaska (Chang 2018). Not only would these changes increase moisture flux into southeast Alaska, but they would also support a warm southwesterly flow, increasing the likelihood that precipitation falls as rain as opposed to snow. Another consequence is that the frequency of rain-on-snow events at 
Juneau is projected to drop to $15 \%-18 \%$ of the $1981-2010$ average by 2071-2100 (Bieniek et al. 2018). However, neither climate model in this study indicated a substantial decrease in mean winter sea level pressure, and the GFDL actually projected domainwide increases (not shown). A second plausible reason for increasing precipitation, absent from changes in the large-scale flow pattern, is from positive Clausius-Clapeyron scaling of water vapor pressure with temperature.

However, projections of spring and summer precipitation amounts did not show substantial changes, which when combined with rising temperatures, present a plausible case for more frequent drought. Zhao and Dai (2015) found that much of southeast Alaska is located in a transition zone wherein the projected (2070-99 relative to 1970-99) ratio of precipitation to potential evapotranspiration increased to the north and decreased to the south. Given the substantial projected decreases in snowfall, which acts as water storage for the region's hydropower dam reservoirs, even minimal increases in summer aridity would exacerbate issues concerning water security. Maximum consecutive 3-day precipitation amounts were projected to increase, but these events typically occur in the autumn and early winter and are frequently associated with atmospheric rivers.

\section{Conclusions}

This study investigated projected changes (2031-60) to the climate of southeast Alaska using dynamically downscaled climate model and reanalysis simulations at 4-km spatial resolution. When compared to earlier dynamically downscaled datasets for this region the data used in this study represent the best combination of spatial and temporal coverage. The historical (1981-2010) CFSR compared favorably with a stationbased statistically downscaled surface temperature product from NCEI; comparison of precipitation between these products highlighted a data assimilation bias in the NCEI product, which suggests an added value of the dynamical products for high-elevation and inland locations. Relative to the historical period, surface temperatures were projected to increase by $1^{\circ}-$ $3^{\circ} \mathrm{C}$ depending on season and model. Precipitation increased during the wet half of the year (i.e., autumn and winter), but was relatively unchanged in spring and summer. Snowfall was projected to decrease in all seasons with the most substantial reductions during autumn and at low elevations.

These distributional changes to temperature and the precipitation variables were further reflected in extremes indices. The number of average annual frost days decreased by more than 30 days, which supports a transition from snow to rain across the landscape. The average annual maximum consecutive 3-day precipitation, a value that is typically recorded in the wet half of the year and is related to flooding risk, increased in both models; yet, increased temperatures combined with stable warm-season precipitation amounts could also increase landscape aridity and heighten the risk of drought. These complex changes were projected using the RCP8.5 emissions scenario, which is often considered the "business as usual" scenario because it tracks best with current greenhouse gas emissions. This implies that the above projections represent a higher-end magnitude of change; however, because the projected period ends at 2060, the choice of scenario matters less than in a projection to 2100 , for example, because of the atmospheric residence time of greenhouse gases and aerosols already emitted (Overland et al. 2014).

Acknowledgments. The authors thank three anonymous reviewers for their comments and suggestions. The project described in this publication was supported by Cooperative Agreement G17AC00213 from the U.S. Geological Survey. Its contents are solely the responsibility of the authors and do not necessarily represent the views of the Alaska Climate Adaptation Science Center or the USGS. This paper is submitted for publication with the understanding that the U.S. government is authorized to reproduce and distribute reprints for governmental purposes. This work was supported in part by the high-performance computing and data storage resources operated by the Research Computing Systems Group at the Geophysical Institute of the University of Alaska Fairbanks.

Data availability statement. The dynamically downscaled data that support the findings of this study are available from corresponding author Lader upon reasonable request. The authors confirm that the station observations are available from the Global Historical Climatology Network Daily database (https:// www.ncdc.noaa.gov/ghcn-daily-description) and the Alaska Climate Division data are available from NOAA NCEI's Climate at a Glance (https://www.ncdc.noaa.gov/cag/).

\section{REFERENCES}

Barnett, T. P., J. C. Adam, and D. P. Lettenmaier, 2005: Potential impacts of a warming climate on water availability in snowdominated regions. Nature, 438, 303-309, https://doi.org/10.1038/ nature04141.

Bathke, D., H. R. Prendeville, A. Jacobs, R. Heim, R. Thoman, and B. Fuchs, 2019: Defining drought in a temperate rainforest. Bull. Amer. Meteor. Soc., 100, 2665-2668, https://doi.org/ 10.1175/BAMS-D-19-0223.1.

Berman, M., and J. I. Schmidt, 2019: Economic effects of climate change in Alaska. Wea. Climate Soc., 11, 245-258, https:// doi.org/10.1175/WCAS-D-18-0056.1.

Bieniek, P. A., J. E. Walsh, R. L. Thoman, and U. S. Bhatt, 2014: Using climate divisions to analyze variations and trends in Alaska temperature and precipitation. J. Climate, 27, 28002818, https://doi.org/10.1175/JCLI-D-13-00342.1.

— , U. S. Bhatt, J. E. Walsh, T. S. Rupp, J. Zhang, J. R. Krieger, and R. Lader, 2016: Dynamical downscaling of ERA-Interim temperature and precipitation for Alaska. J. Appl. Meteor. Climatol., 55, 635-654, https://doi.org/10.1175/JAMC-D-150153.1.

,,,--- R. Lader, B. Griffith, J. K. Roach, and R. L. Thoman, 2018: Assessment of Alaska rain-on-snow events using dynamical downscaling. J. Appl. Meteor. Climatol., 57, 1847-1863, https://doi.org/10.1175/JAMC-D-17-0276.1.

Bourne, S. M., U. S. Bhatt, J. Zhang, and R. Thoman, 2010: Surfacebased temperature inversions in Alaska from a climate perspective. Atmos. Res., 95, 353-366, https://doi.org/10.10 16/ j.atmosres.2009.09.013.

Chang, E. K. M., 2018: CMIP5 projected change in Northern Hemisphere winter cyclones with associated extreme winds. 
J. Climate, 31, 6527-6542, https://doi.org/10.1175/JCLI-D-170899.1.

Cherry, J. E., S. Walker, N. Fresco, S. Trainor, and A. Tidwell, 2010: Impacts of climate change and variability on hydropower in southeast Alaska: Planning for a robust energy future. NOAA Alaska Fisheries Rep., 28 pp., https://repository.library.noaa.gov/ view/noaa/17388.

Dee, D. P., and Coauthors, 2011: The ERA-Interim reanalysis: Configuration and performance of the data assimilation system. Quart. J. Roy. Meteor. Soc., 137, 553-597, https://doi.org/ 10.1002/qj.828.

Diaz, H. F., R. S. Bradley, and L. Ning, 2014: Climatic changes in mountain regions of the American Cordillera and the tropics: Historical changes and future outlook. Arct. Antarct. Alp. Res., 46, 735-743, https://doi.org/10.1657/1938-4246-46.4.735.

Donner, L. J., and Coauthors, 2011: The dynamical core, physical parameterizations, and basic simulation characteristics of the atmospheric component AM3 of the GFDL global coupled model CM3. J. Climate, 24, 3484-3519, https://doi.org/10.1175/ 2011JCLI3955.1.

Feng, S., and Q. Hu, 2007: Changes in winter snowfall/precipitation ratio in the contiguous United States. J. Geophys. Res., 112, D15109, https://doi.org/10.1029/2007JD008397.

Flato, G., and Coauthors, 2013: Evaluation of climate models. Climate Change 2013: The Physical Basis, T. F. Stocker et al., Eds., Cambridge University Press, 741-882, https://doi.org/ 10.1017/CBO9781107415324.020.

Gan, B., L. Wu, F. Jia, S. Li, W. Cai, H. Nakamura, M. A. Alexander, and A. J. Miller, 2017: On the response of the Aleutian Low to greenhouse warming. J. Climate, 30, 3907-3925, https://oi.org/ 10.1175/JCLI-D-15-0789.1.

Gleason, K., A. Smith, C. Fenimore, and R. R. Heim, 2019: United States [in "State of the Climate in 2018']. Bull. Amer. Meteor. Soc., 100 (9), S191-S193, https://doi.org/10.1175/ 2019BAMSStateoftheClimate.1.

Hatchett, B. J., S. Burak, J. J. Rutz, N. S. Oakley, E. H. Bair, and M. L. Kaplan, 2017: Avalanche fatalities during atmospheric river events in the western United States. J. Hydrometeor., 18, 1359-1374, https://doi.org/10.1175/JHM-D-16-0219.1.

Hong, S.-Y., Y. Noh, and J. Dudhia, 2006: A new vertical diffusion package with an explicit treatment of entrainment processes. Mon. Wea. Rev., 134, 2318-2341, https://doi.org/10.1175/MWR3199.1.

Iacono, M. J., J. S. Delamere, E. J. Mlawer, M. W. Shepard, S. A. Clough, and W. D. Collins, 2008: Radiative forcing by longlived greenhouse gases: Calculations with the AER radiative transfer models. J. Geophys. Res. Atmos., 113, D13103, https:// doi.org/10.1029/2008JD009944.

Jacobs, A., E. Holloway, and A. Dixon, 2016: Atmospheric rivers in Alaska-Yes they do exist, and are usually tied to the biggest and most damaging rain-generated floods in Alaska. 2016 Int. Atmospheric Rivers Conf., La Jolla, CA, Center for Western Weather and Water Extremes, http://cw3e.ucsd.edu/ARconf2016/ Posters/Jacobs_IARC2016.pdf.

Knutson, T. R., J. Kam, F. Zeng, and A. T. Wittenberg, 2018: CMIP5 model-based assessment of anthropogenic influence on record global warmth during 2016 [in "Explaining Extreme Events of 2016 from a Climate Perspective"]. Bull. Amer. Meteor. Soc., 99 (1), S11-S15, https://doi.org/10.1175/BAMSD-17-0104.1.

Kunkel, K. E., M. A. Palecki, L. Ensor, D. Easterling, K. G. Hubbard, D. Robinson, and K. Redmond, 2009: Trends in twentieth-century U.S. extreme snowfall seasons. J. Climate, 22, 6204-6216, https://doi.org/10.1175/2009JCLI2631.1.
Lader, R., U. S. Bhatt, J. E. Walsh, T. S. Rupp, and P. A. Bieniek, 2016: Two-meter temperature and precipitation from atmospheric reanalysis evaluated for Alaska. J. Appl. Meteor. Climatol., 55, 901-922, https://doi.org/10.1175/JAMC-D-150162.1.

— J. E. Walsh, U. S. Bhatt, and P. A. Bieniek, 2017: Projections of twenty-first-century climate extremes for Alaska via dynamical downscaling and quantile mapping. J. Appl. Meteor. Climatol., 56, 2393-2409, https://doi.org/10.1175/JAMC-D-160415.1.

,,--- , and -2020 : Anticipated changes to the snow season in Alaska: Elevation dependency, timing and extremes. Int. J. Climatol., 40, 169-187, https://doi.org/10.1002/joc.6201.

Lindsay, R., M. Wensnahan, A. Schweiger, and J. Zhang, 2014: Evaluation of seven different atmospheric reanalysis products in the Arctic. J. Climate, 27, 6051-6073, https://doi.org/10.1175/ JCLI-D-13-00014.1.

Menne, M. J., I. Durre, R. S. Vose, B. E. Gleason, and T. G. Houston, 2012: An overview of the global historical climatology network-daily database. J. Atmos. Oceanic Technol., 29, 897-910, https://doi.org/10.1175/JTECH-D-11-00103.1.

Monaghan, A. J., M. P. Clark, M. P. Barlage, A. J. Newman, and L. Xue, 2018: High-resolution historical climate simulations over Alaska. J. Appl. Meteor. Climatol., 57, 709-731, https:// doi.org/10.1175/JAMC-D-17-0161.1.

Ning, L., and R. S. Bradley, 2015: Snow occurrence changes over the central and eastern United States under future warming scenarios. Sci. Rep., 5, 17073, https://doi.org/10.1038/srep17073.

Niu, G.-Y., and Coauthors, 2011: The community Noah land surface model with multiparameterization options (Noah-MP): 1. Model description and evaluation with local-scale measurements. J. Geophys. Res., 116, D12109, https://doi.org/10.1029/ 2010JD015139.

NOAA National Centers for Environmental Information, 2019: Climate at a Glance: U.S. time series. NESDIS, accessed 11 December 2019, https://www.ncdc.noaa.gov/cag/.

, 2020: State of the Climate: National Climate Report for Annual 2019. Accessed 10 January 2020, https://www.ncdc.noaa.gov/sotc/ national/201913.

Oliver, E. C. J., S. E. Perkins-Kirkpatrick, N. J. Holbrook, and N. L. Bindoff, 2018: Anthropogenic and natural influences on record 2016 marine heat waves [in "Explaining Extreme Events of 2016 from a Climate Perspective"]. Bull. Amer. Meteor. Soc., 99 (1), S44-S48, https://doi.org/10.1175/BAMS-D-17-0093.1.

Overland, J. E., M. Wang, J. E. Walsh, and J. C. Stroeve, 2014: Future Arctic climate changes: Adaptation and mitigation time scales. Earth's Future, 2, 68-74, https://doi.org/10.1002/ 2013 EF000162.

Papineau, J., and E. Holloway, 2011: The nature of heavy rain and flood events in Alaska. NOAA/NWS/ARH Anchorage Forecast Office Research Papers, 20 pp., accessed 14 January 2020, http:// citeseerx.ist.psu.edu/viewdoc/download?doi=10.1.1.729.6444\& rep $=$ rep1\&type $=$ pdf.

Pelto, M., and World Glacier Monitoring Service, 2019: Alpine glaciers [in "State of the Climate in 2018"]. Bull. Amer. Meteor. Soc., 100 (9), S24-S25, https://doi.org/10.1175/ 2019BAMSStateoftheClimate.1.

Pepin, N., and Coauthors, 2015: Elevation-dependent warming in mountain regions of the world. Nat. Climate Change, 5, 424430, https://doi.org/10.1038/nclimate2563.

Peters, G., and Coauthors, 2013: The challenge to keep global warming below $2^{\circ} \mathrm{C}$. Nat. Climate Change, 3, 4-6, https://doi.org/ 10.1038/nclimate1783. 
Riahi, K., and Coauthors, 2011: RCP 8.5-A scenario of comparatively high greenhouse gas emissions. Climatic Change, 109, 33-57, https://doi.org/10.1007/s10584-011-0149-y.

Saha, S., and Coauthors, 2010: The NCEP Climate Forecast System Reanalysis. Bull. Amer. Meteor. Soc., 91, 1015-1057, https:// doi.org/10.1175/2010BAMS3001.01.

Serreze, M. C., M. P. Clark, and A. Frei, 2001: Characteristics of large snowfall events in the montane western United States as examined using snowpack telemetry (SNOTEL) data. Water Resour. Res., 37, 675-688, https://doi.org/10.1029/2000WR900307.

Skamarock, W. C., and Coauthors, 2019: A description of the Advanced Research WRF Model version 4. NCAR Tech. Note NCAR/TN556+STR, 162 pp., https://doi.org/10.5065/1dfh-6p97.

Tabor, K., and J. W. Williams, 2010: Globally downscaled climate projections for assessing the conservation impacts of climate change. Ecol. Appl., 20, 554-565, https://doi.org/10.1890/090173.1.

Tan, Y., F. Zwiers, S. Yang, C. Li, and K. Deng, 2020: The role of circulation and its changes in present and future atmospheric rivers over western North America. J. Climate, 33, 1261-1281, https://doi.org/10.1175/JCLI-D-19-0134.1.

Taylor, K. E., R. J. Stouffer, and G. A. Meehl, 2012: An overview of CMIP5 and the experiment design. Bull. Amer. Meteor. Soc., 93, 485-498, https://doi.org/10.1175/BAMS-D-11-00094.1.

Thoman, R., and J. E. Walsh, 2019: Alaska's changing environment: Documenting Alaska's physical and biological changes through observations. International Arctic Research Center, University of Alaska Fairbanks, accessed 16 January 2020, https://uaf-iarc.org/our-work/alaskas-changing-environment/.
Thompson, G., P. R. Field, R. M. Rasmussen, and W. D. Hall, 2008: Explicit forecasts of winter precipitation using an improved bulk microphysics scheme. Part II: Implementation of a new snow parameterization. Mon. Wea. Rev., 136, 5095-5115, https://doi.org/10.1175/2008MWR2387.1.

Vose, R. S., and Coauthors, 2017: Deriving historical temperature and precipitation time series for Alaska climate divisions via climatologically aided interpolation. J. Service Climatol., 10, https://doi.org/10.46275/joasc.2017.10.001.

Walsh, J. E., and Coauthors, 2018a: The high latitude marine heat wave of 2016 and its impacts on Alaska [in "Explaining Extreme Events of 2016 from a Climate Perspective"']. Bull. Amer. Meteor. Soc., 99 (1), S39-S43, https://doi.org/10.1175/ BAMS-D-17-0105.1.

— for Alaskan stakeholders. Environ. Modell. Software, 110, 3851, https://doi.org/10.1016/j.envsoft.2018.03.021.

Zhang, X., L. Alexander, G. C. Hegerl, P. Jones, A. Klein Tank, T. C. Peterson, B. Trewin, and F. W. Zwiers, 2011: Indices for monitoring changes in extremes based on daily temperature and precipitation data. Wiley Interdiscip. Rev.: Climate Change, 2, 851-870, https://doi.org/10.1002/wcc.147.

Zhao, T., and A. Dai, 2015: The magnitude and causes of global drought changes in the twenty-first-century under a lowmoderate emissions scenario. J. Climate, 28, 4490-4512, https:// doi.org/10.1175/JCLI-D-14-00363.1.

Zhu, Y., and R. E. Newell, 1994: Atmospheric rivers and bombs. Geophys. Res. Lett., 21, 1999-2002, https://doi.org/10.1029/ 94GL01710. 